KIRJALLISUUTTA

\title{
Verkkokeskusteluiden historiaa tutkimassa
}

\author{
Ari Haasio \\ Seinäjoen ammattikorkeakoulu \\ ari.haasio@seamk.fi \\ https://orcid.org/0000-0003-3723-4890
}

Arvio teoksesta Suominen, J., Saarikoski, P. \& Vaahensalo, E. 2019. Digitaalisia kohtaamisia: verkkokeskustelut BBS-purkeista sosiaaliseen mediaan. Helsinki: Gaudeamus. 323 s.

Asiasanat: keskusteluryhmät, chatit, internetin historia, digitaalinen kulttuuri, verkkokeskustelut

Internetistä on muodostunut merkittävä keskustelufoorumi ennen muuta 200o-luvulla sosiaalisen median läpimurron ansiosta. Verkko on kuitenkin aina ollut interaktiivinen foorumi ja vilkas keskustelu on ollut sille tyypillistä alusta alkaen, kuten Katz ja Rice (2002) korostivat jo 2000-luvun alussa. Alkuvaiheessa kyse oli suppean harrastajajoukon puuhastelusta, nyt verkko on kaikkien kansalaisten käyttämä keskustelufoorumi. Suominen ja kumppanit valottavat lyhyesti verkkokeskustelujen varhaisvaiheita ja tarkasteluväli on 1980-luvun purkkien synnystä alkaen aina nykypäivän ilmiöihin.

Artikkeli on lisensoitu Creative Commons Nimeä-EiKaupallinen-JaaSamoin 4.o Kansainvälinen -lisenssillä

Pysyvä osoite: https://doi.org/10.23978/inf.88770 
Suominen ja kumppanit eivät tyydy vain käymään läpi eri palveluja ja analysoimaan niiden historiallista kehityskaarta. Sen sijaan he tuovat hyvin esiin verkkokeskusteluihin liittyvää monisäikeistä problematiikkaa. Esimerkiksi uutisryhmiin liittyvät käyttäytymiskoodiston pohdinta ja verkkokeskustelujen luonteen muuttuminen tuo uusia näkökulmia verkkokulttuurin ymmärtämiseen. Verkkokeskustelujen varhaisvaiheessa monilla oli idealistinen ajatus siitä, kuinka avoin keskustelu mahdollistaa demokratian paremman toteutumien. Suominen ja kumppanit tuovat hyvin esiin myös tämän idealismin romuttumisen: alkuaikojen yhteisöllisyys on muuttunut paikoitellen sananvapauden nimissä tehdyiksi ylilyönneiksi ja verkkovihaksi.

Jaakko Suominen, Petri Saarikoski ja Elina Vaahensalo ovat kirjoittaneet kokonaisvaltaisen esityksen kotimaisten verkkokeskustelujen historiasta. Teoksen alaotsikko BBS-purkeista sosiaaliseen mediaan havainnollistaa hyvin, kuinka alustat ovat kehittyneet ja monipuolistuneet. Historiallinen näkökulma verkon kehitykseen on tervetullut lisä aihepiirin tutkimukseen. Vaikka painopiste on kotimaisten verkkokeskustelujen historiassa, kirjoittajat huomioivat myös kansainvälisesti merkittävät trendit ja palvelut. Esimerkiksi kuvalautojen edelläkävijänä pidetty 4chan ja anonyymin sisällönjakamisen mahdollistava Reddit ja niiden merkitys keskustelukulttuurille käsitellään perusteellisesti. Sama koskee myös monia muita kansainvälisiä verkon keskustelufoorumeita.

\section{Yhteisöllisyydestä vihapuheeseen}

Alkuaikojen purkkien yhteisöllisyys ja merkitys kohtaamispaikkoina tulee selkeästi esiin. Purkeissa kulutettiin aikaa, viihdyttiin ja solmittiin tuttavuuksia. Ne olivat parhaimmillaan lämminhenkisiä, suhteellisen pienen piirin käyttämiä keskustelufoorumeja, joiden jäsenistä iso osa jopa tunsi toisensa. Kirjoittajat ovat käyttäneet aineistona BBS Kukkaniittu ja BBS Atom Heart Mother -purkkeja, joiden keskustelut ovat säilyneet tutkijoiden käyttöön. Kirjoittajien mukaan ne ovat oivia esimerkkejä 1990-luvun lopun purkeista, joiden keskusteluiden sävy oli "toverillinen ja lempeän piikittelevä”.

Suomisen ja kumppaneiden keskustelujen sisällönanalyysi osoittaa hyvin keskustelukulttuurin muutoksen. Alkuaikojen yhteisöllisyys on muuttunut: monet keskustelupalvelut ovat massojen valtaamia ja keskustelun sävy on muuttunut. Ennen muuta aggressioiden ja vihapuheen lisääntyminen sekä erilaisten muiden verkon negatiivisten piirteiden yleistyminen keskustelufoorumeilla tulee selkeästi esiin. Vauva.fi ja etenkin Suomi24 -palstojen analyysi osoittaa, että ne ovat olleet tärkeitä mielipiteiden ilmaisufooru- 
meita, mutta valitettavasti etenkin jälkimmäisellä myös verkkokeskusteluiden negatiiviset piirteet ovat olleet valitettavan yleisiä. Kirjoittajat kutsuvatkin Suomi24-palvelua "kansalliseksi purkauskanavaksi", mikä kuvastaa hyvin maamme kautta aikain suosituimman keskustelukanavan olemusta. Vaikka tekijät toteavat epilogissa, että he eivät ota kantaa siihen, onko esimerkiksi vihapuheen määrä verkkokeskusteluissa lisääntynyt ja verkkokeskustelun laatu parantunut tai heikentynyt, selkeitä trendejä lukija voi kuitenkin hahmottaa.

Sosiaalisen median läpimurto 2000-luvun ensimmäisellä vuosikymmenellä muutti keskustelukulttuurin luonnetta. Iso osa keskusteluista siirtyi pois keskustelupalstoilta sosiaaliseen mediaan. Suominen ja kumppanit tuovat hyvin esiin verkolle tyypillisen sosiaalisuuden ja interaktiivisuuden jo kauan ennen sosiaalisen median syntyä.

\section{Mobiili keskustelukulttuuri}

Kirjan toiseksi viimeisessä luvussa käsitellään mobiiliteknologian vaikutusta keskustelukulttuuriin. Aihe on tärkeä ja kirjoittajat ovat onnistuneet luomaan hyvän yleiskatsauksen mobiilipalvelujen historiaan verkkokeskustelujen näkökulmasta. Aihe jatkuu tavallaan myös kirjan päätösluvussa, jossa käsitellään Messengerin ja WhatsAppin kaltaisia sosiaalisen median sovelluksia ja niiden merkitystä keskustelukulttuurin näkökulmasta.

Pikaviestimet ovat looginen jatkumo tekstiviesteille, joiden varhaisvaiheet tuodaan myös esiin kiitettävästi. Useiden eri tutkimusten mukaan mobiiliviestinnän ja verkon mobiilikäytön merkitys on suuri etenkin nuoremmissa ikäryhmissä. Suomisen ja kumppaneiden havainnot mobiiliviestinnän merkityksistä selittävät osaltaan tätä ilmiötä keskustelukulttuurin näkökulmasta. Voisi jopa sanoa, että Messenger ja WhatsApp ovat luoneet aivan uudenlaisen yhteydenpitokulttuurin, jonka edelläkävijänä toimivat tekstiviestit. Vaikka verkkokeskustelut on helppo mieltää vain tietokoneavusteisesti tai mobiiliteknologiaa hyödyntäviksi palveluiksi, Digitaalisia kohtaamisia tuo hyvin esiin sen, että esimerkiksi TV-chatit ovat olleet merkittäviä edelläkävijöitä.

\section{Kattava kokonaiskuva}

Suominen ja kumppanit havainnollistavat hyvin verkkokeskustelujen moninaisuuden, lieveilmiöt ja mahdollisuudet. Teoksesta välittyy hyvin myös paitsi keskustelukulttuurin, myös teknologian mukanaan tuoma muutos. Verkkokeskustelut ovat tulleet edelläkävijöinä toimineen pienen harrastajayhteisön 
ajanvietteestä osaksi kaikkien kansalaisten osallistumista ja kommunikointia.

Marginaalisena puutteena voi pitää sitä, että kirjassa ei juuri huomioida Tor-verkkoa ja siellä tapahtuvaa keskustelua. Vaikka iso osa Torissa tapahtuvasta toiminnasta on illegaalia, olisi Torin ja siellä tapahtuvan keskustelun lyhyt esittely ollut oiva lisä. Tor-verkon kuvalaudoilla kommunikointi on erittäin vilkasta; kotimaisissa palveluissa liikkuu vuositasolla ainakin toista miljoonaa viestiä. Tor-verkossa on myös avoimesta verkosta poikkeava keskustelukulttuuri, minkä vuoksi sen esittely olisi ollut paikallaan. Myös sosiaalisen median eräät keskustelufoorumit, kuten Facebookin ryhmät, jäävät ehkä turhankin vähälle käsittelylle. Eri ryhmillä on erilaisia funktioita aina harrasteista huumoriin ja yhteiskunnallisesta keskustelusta markkinointiin. Myös aikuisviihteellä on aina ollut keskeinen rooli internetissä. Kotimaiset Livechatin kaltaiset chat-palvelut ovat yksi verkkokeskustelujen muoto ja ne olisi voinut myös ottaa mukaan kirjaan.

Kirjan loppuun liitetty verkkokeskustelujen historiaa havainnollistava aikajana on erinomainen lisä. Sen avulla on helppo hahmottaa eri palvelujen kehityskaari BBS-purkeista sosiaalisen median eri palvelujen syntyyn. Samalla aikajana osoittaa myös sen, että monet suositut keskustelufoorumit ovat melko nopeasti tulleet tiensä päähän. Kuten kirjoittajat toteavat itsekin, monien foorumeiden elinkaari on lyhyt.

Suomisen ja kumppaneiden ote on kriittinen: heidän analyysinsä verkkokeskustelujen sisällöistä tuo tervetulleen lisän alan kirjallisuuteen. Ennen muuta alkuaikojen purkkeja ja uutisryhmiä eli nyyssejä koskeva osa on tutkimuksessakin ollut vähemmän esillä ja lukija saa hyvän kokonaiskuvan ajasta ennen vuotta 2000.

Kirjan parasta antia on ennen muuta verkkokeskusteluihin liittyvien eri ilmiöiden analyysi: esimerkiksi meemeihin ja niiden kehitykseen on pureuduttu havainnollisesti. Tekijät pohtivat eri tyyppisiä verkkokeskusteluja myös sisällöllisesti, mikä tuo lisäarvoa teokselle. Digitaalisia kohtaamisia piirtää lukijalle onnistuneen kokonaiskuvan eri verkkopalvelujen kehityskaaresta, niiden moninaisuudesta ja ennen muuta keskustelukulttuurin muutoksesta. Netiketin pohdinta ja erityyppisten keskustelufoorumeiden erilaisen sallivuuden analyysi tuo myös syvyyttä verkkokulttuurista muodostuvan kokonaiskuvan saamiseen.

Kokonaisuutena Suomisen ja kumppaneiden teos on tervetullut lisä alan kotimaiseen kirjallisuuteen. Se on monipuolinen ja kattava tietopaketti aiheesta ja soveltuu hyvin esimerkiksi ammattikorkeakoulujen ja yliopistojen kurssikirjaksi alan perusopintoihin. 


\section{Lähteet}

Katz, J. E. \& Rice, R. E. 2002. Social Consequenses of Internet Use. Access, Involvement, and Interaction. Cambridge, MA: MIT Press. 